\title{
Mobile epifaunal community in marine caves in comparison to open habitats
}

\author{
Carlos Navarro-Barranco',* , José Manuel Guerra-García1 , Luis Sánchez-Tocino², \\ José Carlos García-Gómez ${ }^{1}$
}

${ }^{1}$ Laboratorio de Biología Marina, Dpto. Zoología, Facultad de Biología, Universidad de Sevilla, Avda Reina Mercedes 6, 41012 Sevilla, Spain

${ }^{2}$ Departamento de Biología Animal, Facultad de Ciencias, Universidad de Granada, Campus Universitario de Fuentenueva, s/n., 18071 Granada, Spain

\begin{abstract}
Mobile epifauna is an essential component of rocky reef ecosystems. In spite of this and the great scientific interest that the study of marine caves has aroused in the last decades, little research has been conducted on the macrofauna associated with animal substrates in submarine caves. This study explores the main differences between marine caves and open habitats in terms of species composition and diversity patterns of epifaunal communities in 4 different shallow marine caves in southern Spain. Colonies of Eudendrium sp., a marine hydroid widely distributed in the Mediterranean Sea, were taken from inside and outside each cave, and all associated mobile fauna were sorted and identified. More than $90 \%$ of organisms were crustaceans, with Amphipoda as the dominant group. Although the main species did not vary significantly in abundance between open and cave habitats, multivariate analysis carried out for the entire amphipod community showed significant differences between these 2 habitats. nMDS analysis showed that marine cave assemblages were also characterized by a higher degree of individuality, and univariate analysis showed a decrease in Shannon diversity and species richness with distance into the caves, a consistent pattern for all caves studied. Although the possible role of predation pressure in the structure of such assemblages was also discussed, we propose that the absence of plant substrates inside the caves, in conjunction with oligotrophic conditions and low siltation, are the main factors responsible for the impoverishment of the epifaunal community. The near lack of photosynthetic activity reduced the presence of herbivorous species, while the rich detritus-feeder community supported by the animal substrates was limited by the low rate of sedimentation.
\end{abstract}

KEY WORDS: Epifauna $\cdot$ Marine caves $\cdot$ Amphipods $\cdot$ Hydroids $\cdot$ Mediterranean Sea

\section{INTRODUCTION}

Marine caves constitute a typical feature of the Mediterranean coastline. Because of their high vulnerability and important role as a biodiversity reservoir (Gerovasileiou \& Voultsiadou 2012), marine cave habitats are protected by the European Community (Habitat Directive 92/43 EEC). Darkness is not the only peculiarity of this ecosystem; because of their isolation, lack of photosynthetic production, long- term stability, similarity to the bathyal zone and presence of strong environmental gradients on spatial scales of only a few meters, marine caves have long been considered as environments of great taxonomic and ecologic interest (Vacelet et al. 1994, BenedettiCecchi et al. 1997, Hiscock \& Breckels 2007). Several comparative studies have been done to explore the differences in distribution of organisms inside marine caves versus open habitats (e.g. Zabala et al. 1989, Harmelin 1997, Martí et al. 2004, Bussotti \& Guidetti 
2009, Janssen et al. 2013). However, only a few of these studies have taken into account the epifaunal community inhabiting animal or plant substrates (Ledoyer 1966, True 1970, Scipione et al. 1981). Thus, this type of assemblage remains poorly known, although it is essential to consider this part of the marine cave community in order to understand the behavior of these systems. Epifauna associated with hard-bottom substrates are major contributors to the flux of materials in rocky habitats, providing up to $99 \%$ of total secondary productivity, and acting as a prey source for the majority and most productive demersal fishes (Taylor 1998a, Edgar \& Aoki 1993). However, they have usually been excluded in trophic models (Taylor 1997).

Although a decrease in species richness, diversity and coverage of benthic organisms is a well-known phenomenon in the inner part of marine caves (Zabala et al. 1989, Bussotti et al. 2006), the existence of the same pattern for the epifaunal community has not been tested. The presence of sessile species has a positive effect on the diversity of associated assemblages, which is evident when we compare them to bare rock and sedimentary environments (Chapman et al. 2005, Birdsey et al. 2012). Thus, one could expect that because of the oligotrophic conditions and high percentage of bare substrate in these habitats, caves might support a poor assemblage of mobile organisms. However, the decline in competition for substrate by algae in the semi-dark areas of marine caves often allows for the development of a rich and heterogeneous community dominated by sessile invertebrates (Bussotti et al. 2006).

With respect to differences in species composition, obviously if the benthic community is different between marine caves and open habitats, the associated epifauna will likely also differ (Birdsey et al. 2012). Previous studies have highlighted how macroinfauna associated with soft sediments inside marine caves was different from those present outside them (Bamber et al. 2008, Navarro-Barranco et al. 2013). However, it is difficult to establish how many of those differences in community are due to habitat, because of the presence of confounding factors such as changes in the granulometry or the chemical properties of the sediment. Thus, in the present study we explore the mobile organisms associated with Eudendrium sp. (Cnidaria, Hydrozoa), a substrate present in both habitats (semi-dark and open). By using the same substrate, we can identify the extent the environment (and not the change of substrate) plays in determining changes in epifaunal composition and biodiversity patterns.
Cnidarian colonies can support a highly diverse epifaunal community, as has been shown in gorgonian gardens and scleractinian reefs (Stella et al. 2010, Carvalho et al. 2014). Hydroids are also considered to be a foundation species of littoral communities in temperate habitats (Bavestrello et al. 1996). Simkina (1980) pointed out that hydroid colonies can constitute the major regulators of zooplankton in some areas, playing an important role in the mass development of copepod species. They also act as a food supply for many species, such as nudibranchs and amphipods (Bavestrello et al. 1996). Moreover, specific studies have highlighted the biodiversity increase of epifauna in rocky habitats when hydroid colonies were present (Bradshaw et al. 2003). Eudendrium is a common and widely distributed hydroid genus in both natural and polluted Mediterranean environments, forming large arborescent colonies which support a rich community of sessile and mobile epibiontic organisms (Bavestrello et al. 1996, Romagnoli et al. 2007, Di Camillo et al. 2008). Among its mobile epifauna, crustaceans (mainly copepods and amphipods) comprise more than $90 \%$ of individuals (Bavestrello et al. 1996); a common feature in most benthic substrates and habitats (and also inside marine caves) (Martin-Smith 1993, Taylor 1997, Fredriksen et al. 2005, Guerra-García et al. 2011, NavarroBarranco et al. 2012). Because of their abundance, ubiquity, importance in the structure of benthic assemblages and sensitivity to environmental changes, amphipod crustaceans are often used as a model group in ecological studies (Sánchez-Moyano \& García-Gómez 1998, Duffy \& Hay 2000, Guerra-García \& García-Gómez 2001).

The main objective of this study was to explore the ecological patterns that characterize mobile epifaunal communities in marine caves. For that, we used the amphipod community associated with Eudendrium sp. as a model, studying the possible existence of differences in the abundance, number of species, diversity and species composition in the epifauna associated with hard-bottom communities between marine caves and open habitats.

\section{MATERIALS AND METHODS}

\section{Study site and sampling collection}

Four shallow marine caves were selected and sampled between 20 and 28 August 2012 in La Herradura (southern Spain): 'Cueva de la Punta del Vapor' $\left(36^{\circ} 43^{\prime} 22^{\prime \prime} \mathrm{N}, 3^{\circ} 42^{\prime} 35^{\prime \prime} \mathrm{W}\right)$, 'Cueva del Jarro' 
$\left(36^{\circ} 43^{\prime} 11^{\prime} \mathrm{N}, 3^{\circ} 43^{\prime} 48^{\prime} \mathrm{W}\right)$, 'Cueva de los Gigantes' $\left(36^{\circ} 43^{\prime} 20^{\prime \prime} \mathrm{N}, 3^{\circ} 44^{\prime} 08^{\prime \prime} \mathrm{W}\right)$, and 'Cueva de CerroGordo' $\left(33^{\circ} 43^{\prime} 46^{\prime \prime} \mathrm{N}, 3^{\circ} 45^{\prime} 56^{\prime \prime} \mathrm{W}\right)$. All of these caves are shallow (samples were taken between 6 and $12 \mathrm{~m}$ deep) and showed a similar topography in their semidark areas. Two sampling stations were selected in each location: one in the exterior area (approximately $5 \mathrm{~m}$ outside the cave mouth) and another inside the cave. The abundance of Eudendrium sp. decreases in the inner part of the caves, being absent in the completely dark areas. Therefore, the cave samples were taken in the semi-dark area (approximately $10 \mathrm{~m}$ from the entrance), where the abundance of Eudendrium sp. remains similar to that present outside the caves. Although the distance between the 2 stations in each cave was only ca. $15 \mathrm{~m}$, the caves showed marked gradients in many factors, such as light and hydrodynamism. Therefore, changes between both communities were very evident, with an algaedominated community on one side and an invertebrate-dominated community on the other. Four replicate samples of Eudendrium sp. were collected at each station by divers using SCUBA equipment. Each colony was enveloped in a plastic bag before detachment to avoid the loss of organisms, and preserved in $70 \%$ ethanol. In the laboratory, each colony was washed through a $0.1 \mathrm{~mm}$ mesh sieve with fresh water to collect all mobile organisms, and the volume of each colony was measured by the displacement of a known volume of water when the hydroid was introduced. The organisms were sorted into higher taxa and counted. Additionally, all amphipods were identified to species level using a binocular microscope.

\section{Data analysis}

Abundance per taxon was calculated for each station (mean $\pm \mathrm{SD}$ ). For amphipod crustaceans, the number of species (mean $\pm \mathrm{SD}$ ) and ShannonWiener diversity index (Shannon \& Weaver 1963) were also calculated. The spatial variation in these parameters for the amphipod community was explored using ANCOVA with 2 factors: habitat (Ha) and location (Lo). Habitat was a fixed factor with 2 levels (internal vs. external stations). Location was a fixed factor, orthogonal with habitat, with 4 levels (one for each marine cave). Four samples were considered for each station $(\mathrm{n}=4)$. Volume was included as a covariate. It has been proven that the inclusion of factors that cannot be controlled experimentally as covariates increases the power of the statistical analysis (Huitema 2011, Quinn \& Keough 2002). Heterogeneity of variance was checked using Cochran's test, and transformations were applied when necessary (Underwood 1997). When variances remained heterogeneous, untransformed data were analyzed, as ANOVA is robust enough to support conclusions based on this assumption - particularly in a balanced design with sufficient replicates (Underwood 1997). In such cases, special care was taken in the interpretation of results, and in order to reduce Type I errors, the level of significance was reduced to 0.01 . Prior to analysis, heterogeneity of slopes was also tested by crossing the covariate with the interaction of the other 2 factors and checking for significant interactions (Engqvist 2005). Taking into account that colony volume was not a significant covariate in any analysis, the same general design was tested with an ordinary ANOVA (Quinn \& Keough 2002, Martins et al. 2007), with 2 factors. When ANOVA indicated a significant difference for a given factor, the source of difference was identified using the Student-Newman-Keuls (SNK) tests.

Multivariate analyses were conducted using the abundances of amphipod species per replicate. Data were previously square-root transformed to reduce the importance of extreme values, and a similarity matrix was generated using the BrayCurtis similarity index. In order to test differences in amphipod species compositions, a distancebased permutational multivariate analysis of variance (PERMANOVA) was carried out using the previous 2 -factor design. Terms found to be significant in the analyses were examined individually using appropriate pair-wise comparisons. A nonparametric multidimensional scaling (nMDS) using the mean values per station was carried out to explore differences in species composition between habitats and locations. A permutational analysis of multivariate dispersions (PERMDISP) was carried out to test differences in the variation of the amphipod community between cave and external habitats. SIMPER was used to calculate the contribution of each species to the observed dissimilarity between internal and external stations. ANOVA was used for those species with higher contribution, to test whether their abundance was different across habitats.

ANOVA analyses were performed using the GMAV5 program (Underwood et al. 2002) and ANCOVA using SPSS.15. Multivariate analyses were carried out using the PRIMER v.6 + PERMANOVA package (Clarke \& Gorley 2001). 


\section{RESULTS}

A total of 2877 organisms were collected in the study. Arthropods made up the most abundant group in all stations (Fig. 1), and with the exception of a few pycnogonids, all of the arthropods were crustaceans. Molluscs (mainly nudibranchs and bivalves) represented $3.8 \%$ of organisms, $2.5 \%$ were annelids (polychaetes) and $1 \%$ were echinoderms. Within crustaceans, $98.6 \%$ were amphipods while the rest were comprised of tanaids, isopods, decapods and cumaceans. Nineteen different amphipod species (17 gammarids and 2 caprellids) were found on Eudendrium sp. (Table 1). The caprellid Pseudoprotella phasma var. minor was the most abundant species, constituting $58 \%$ of the organisms, and reaching densities higher than 50 ind. $\mathrm{cm}^{-3}$ in some colonies. The gammarids Ischyrocerus inexpectatus, Lembos websteri and Stenothoe sp. were also very abundant, while other species such as Amphilochus neapolitanus, Liljeborgia sp. or Ampithoe ramondi were only represented by a few organisms. According to the univariate analyses, the diversity of amphipod communities associated with Eudendrium sp. was significantly lower inside the caves (Table 2). No differences were detected among locations, and the absence of a significant interaction between factors $(\mathrm{Ha} \times$ Lo) allows us to consider that the diversity decrease inside caves was a constant pattern in all

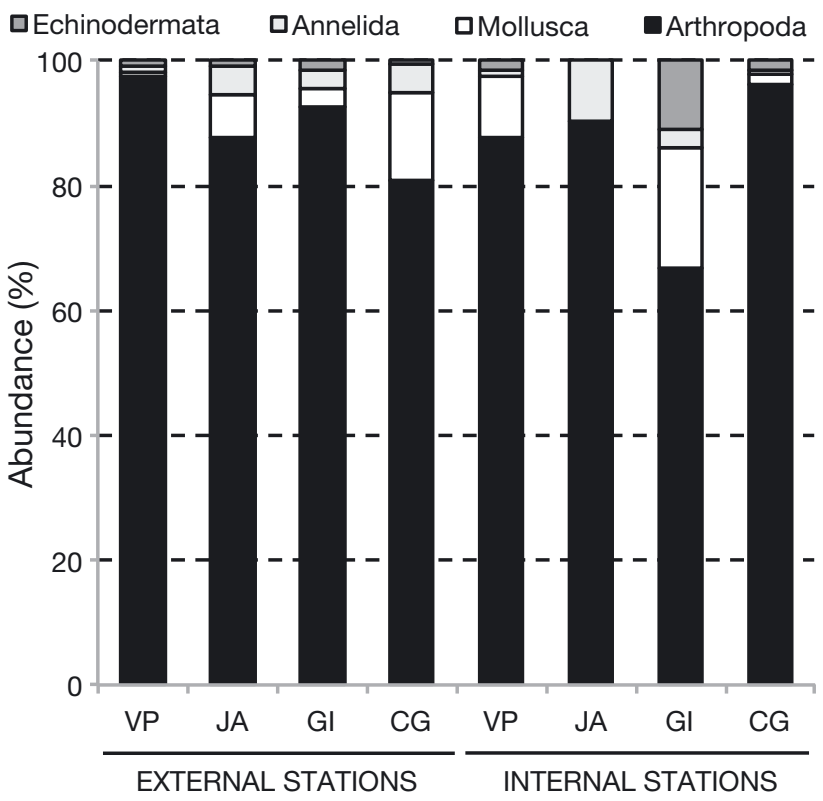

Fig. 1. Abundance (\%) of each phylum collected per station. External stations were located approximately $5 \mathrm{~m}$ outside the mouth of the cave; internal stations were in the semidark area approximately $10 \mathrm{~m}$ from the cave entrance

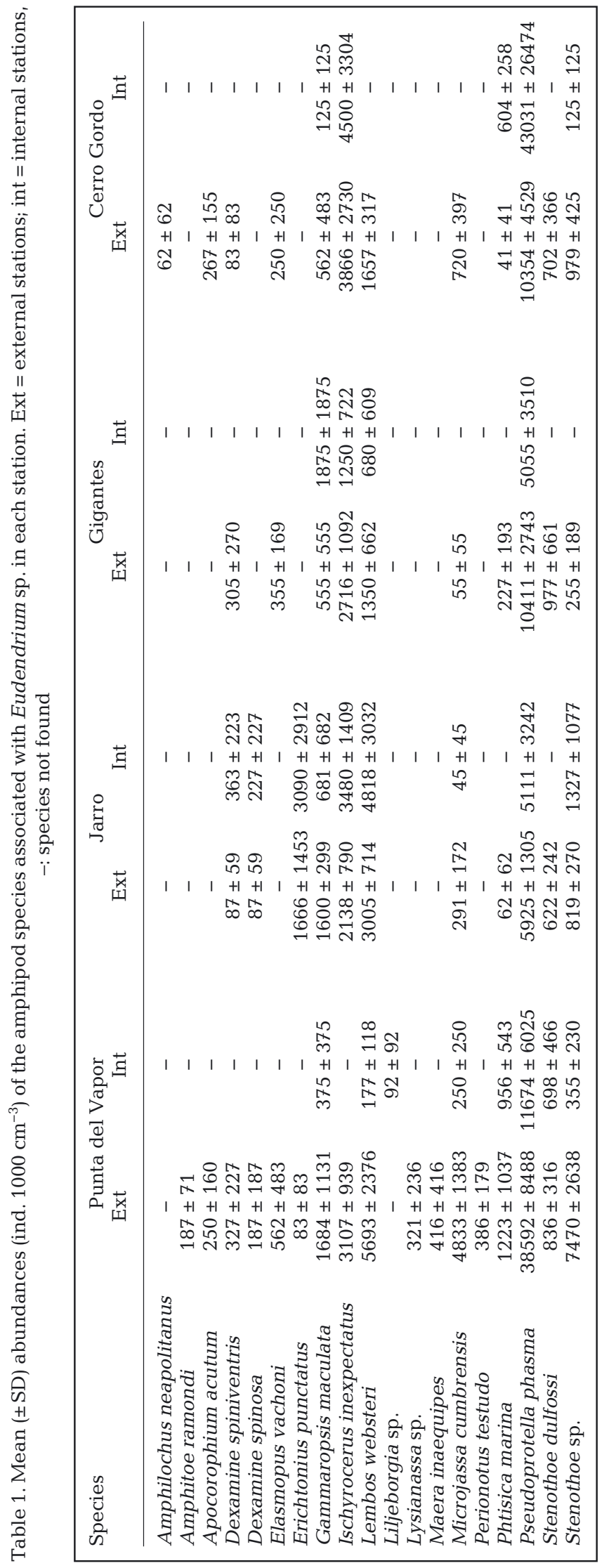


Table 2. Results of 2-way ANOVA for Shannon-Wiener diversity, species richness and abundance of individuals for the amphipod community. No transformations were necessary for diversity and richness values, while abundance data were log transformed. ${ }^{*} \mathrm{p}<0.05 ;{ }^{* *} \mathrm{p}<0.01 ;{ }^{* * *} \mathrm{p}<0.001$

\begin{tabular}{|c|c|c|c|c|c|c|c|c|c|c|}
\hline \multirow[t]{2}{*}{ Source of variation } & \multirow[b]{2}{*}{$\mathrm{df}$} & \multicolumn{3}{|c|}{ Shannon diversity } & \multicolumn{3}{|c|}{ Species richness } & \multicolumn{3}{|c|}{ Abundance of organisms } \\
\hline & & MS & $F$ & $\mathrm{p}$ & $\mathrm{MS}$ & $F$ & $\mathrm{p}$ & MS & $F$ & $p$ \\
\hline Habitat = (Ha) & 1 & 3.07 & 16.55 & $0.000^{* * *}$ & 190.13 & 43.25 & $0.000^{* * *}$ & 22.78 & 20.83 & $0.000^{* * *}$ \\
\hline Location $=($ Lo $)$ & 3 & 0.49 & 2.66 & 0.071 & 28.54 & 6.49 & $0.002^{* *}$ & 3.1 & 3.66 & $0.027^{*}$ \\
\hline Ha $\times$ Lo & 3 & 0.2 & 1.08 & 0.377 & 8.21 & 1.87 & 0.162 & 3.45 & 3.16 & $0.043^{*}$ \\
\hline Residual & 24 & 0.19 & & & 4.4 & & & 1.09 & & \\
\hline
\end{tabular}

locations. Habitat was also a significant factor in species richness (Table 2). Colonies of Eudendrium sp. situated inside the caves hosted less than half of the number of species compared to colonies inhabiting open habitats (Fig. 2). All species in the study were present in external stations, but only 12 were present in the colonies inside the caves. Location was also a significant factor, but the patterns were still constant (Ha $\times$ Lo not significant). Concerning abundance analysis, there were significant differences between habitats and locations, but these differences were not constant (Table 2). For example, external colonies in Punta del Vapor contained 10 times more individuals than internal ones, while in Cerro-Gordo the abundances were higher inside the cave (Fig. 2). The abundance increase inside Cerro-Gordo cave was due to an unusual rise in the number of Pseudoprotella phasma.

PERMANOVA results showed significant differences in the amphipod community between habitats and among locations (Table 3), with no interaction between them. A clear separation between internal and external communities was not found in the nMDS (Fig. 3), although a higher variability of internal stations among caves in comparison with external ones can be observed. PERMDISP results indicated that cave habitats showed a significantly greater variation than external habitats $(p<0.05)$. The uni- variate analyses carried out for each of the main species separating habitats (according to SIMPER results) did not show any significant differences between internal and external areas.

\section{DISCUSSION}

\section{Mobile epifaunal community associated with Eudendrium sp.}

The dominance of crustaceans observed in the present study agrees with most of the studies carried out for epifaunal communities associated with hard substrates (see references in the 'Introduction'). Polychaetes were also established as the dominant epifaunal group in some areas, but this is usually due to the highly polluted conditions of these environments (Dean 2008). All amphipod species found in the study had been previously recorded as inhabiting multiple hosts (Bellan-Santini et al. 1982, 1989, 1993). Although some amphipod species have shown strong host specificity (Poore et al. 2000, Gestoso et al. 2013), hard substrate epifaunal taxa (amphipods included) generally do not show habitat specialization (Taylor 1997). Moreover, Eudendrium sp. and most benthic hydroids in temperate waters are subjected to sharp seasonal variations in abundance
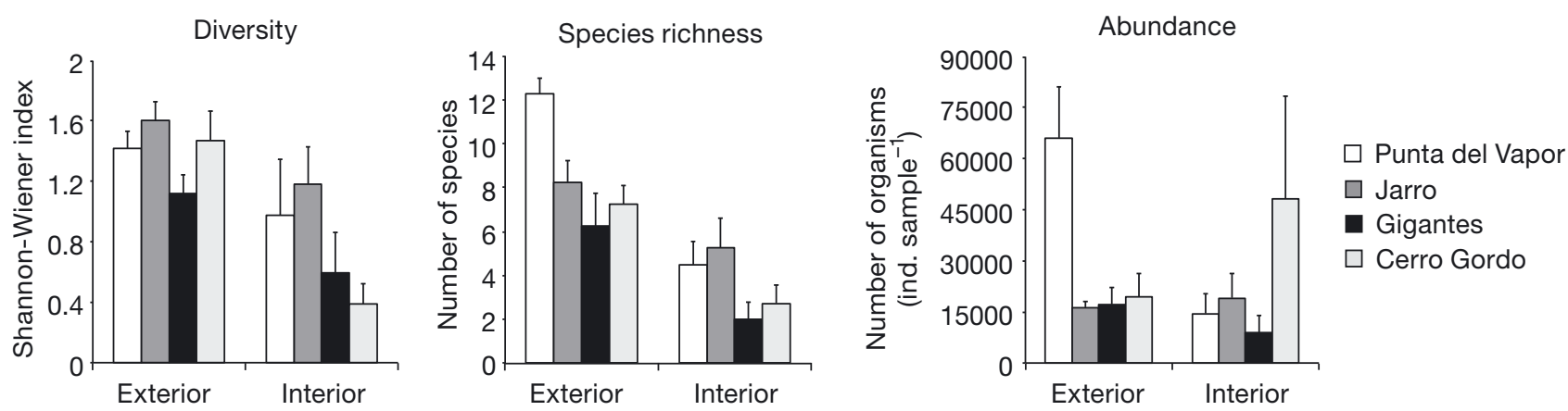

Fig. 2. Mean values $( \pm \mathrm{SD})$ of Shannon-Wiener diversity index, number of species and abundance of organisms (ind. sample ${ }^{-1}$ ) inside and outside the caves 
Table 3. Results of the multivariate PERMANOVA for amphipod assemblages, based on Bray-Curtis dissimilarities of square-root transformed data. ${ }^{* *} \mathrm{p}<0.01$

\begin{tabular}{|lrccc|}
\hline Source of variation & df & MS & $F$ & $p$ \\
\hline Habitat $=(\mathrm{Ha})$ & 1 & 4926.4 & 3.224 & $0.003^{* *}$ \\
Location $=($ Lo $)$ & 3 & 3203.5 & 2.096 & $0.007^{* *}$ \\
Ha $\times$ Lo & 3 & 2364.7 & 1.548 & 0.078 \\
Residual & 24 & 1528.1 & & \\
\hline
\end{tabular}

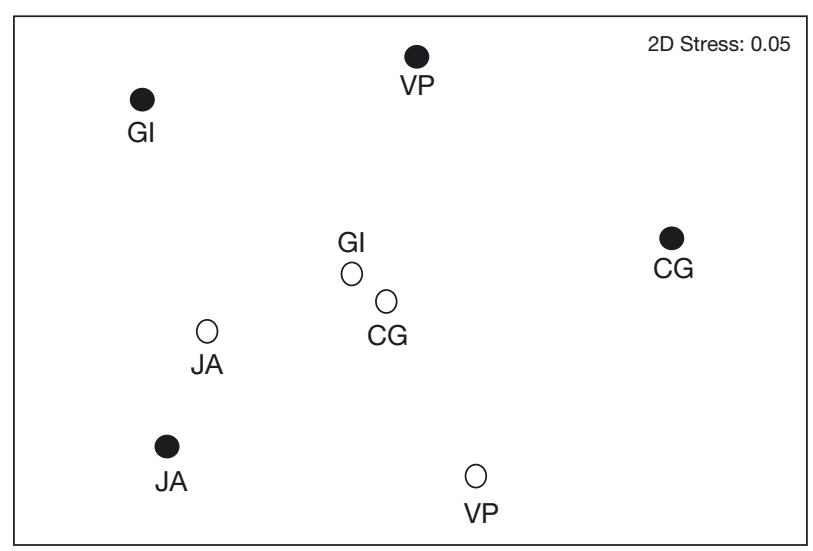

Fig. 3. Two-dimensional non-parametric multidimensional scaling (nMDS) plot for species composition inside and outside the marine caves. Data were square-root transformed. Black circles represent internal stations; white circles represent external ones. $\mathrm{VP}=$ Cueva del Vapor; JA = Cueva del Jarro; GI = Cueva de los Gigantes; CG = Cueva de Cerro Gordo

(Bavestrello et al. 2006, Di Camillo et al. 2012), which might promote lower rates of specialization (Duffy \& Hay 1991, Chemello \& Milazzo 2002). For example, stenothoids are predominantly found on cnidarians, but also occur on algae, tunicates, sponges, etc. (Bellan-Santini et al. 1993, Vader \& Krapp-Schickel 1996). Ischyrocerus inexpectatus, the second most abundant species found in our study, is also present in other substrates such as algae and bryozoans, and was only reported to occur occasionally on Eudendrium glomeratum (Bellan-Santini et al. 1989, Bavestrello et al. 1996, Conradi et al. 2000). Only Pseudoprotella phasma, the most abundant species in the study, seemed to show a clear preference for hydroids (J. M. Guerra-García unpubl. data), which could be due to the close kleptocommensalism relationship that has been reported between P. phasma and Eudendrium sp. (Bavestrello et al. 1996).

The diverse epifaunal community hosted by $\mathrm{Eu}$ dendrium sp. is usually explained by its role as a small ecosystem engineer (Bavestrello et al. 1996).
Since Eudendrium sp. is among the few erect and ramified organisms living inside marine caves, it could be expected that the role of this hydroid in terms of epifaunal diversity is especially important in this habitat.

\section{Differences between marine caves and open habitats}

The high variability observed in the internal samples is a common feature reported in marine caves. Several factors (e.g. depth, cave topography, size and orientation of entrance) can influence environmental conditions inside caves, which creates a high degree of individuality in these habitats (Bussotti et al. 2006, Navarro-Barranco et al. 2013).

Regarding amphipod distribution, no species were exclusive of cave environments. That was to be expected, since the samples were not taken in the inner and most isolated part of the caves, and the vast majority of the species recorded in marine caves are stygophilic (not specialized in subterranean life, found in other similar habitats as well) or stygoxenes (sheltering in caves but feeding outside) (Scipione et al. 1981, Gerovasileiou \& Voultsiadou 2012). The absence of significant differences between internal and external areas of the caves in terms of the main species separating habitats is remarkable, since some of them, such as Lembos websteri or Ischyrocerus inexpectatus, are often related to exposed environments.

In spite of the absence of significant differences between habitats with respect to specific species, the analysis for the whole community showed clear differences between external and internal habitats, with a decrease in species richness and diversity in the latter. What factor(s) could be responsible for these differences? Unfortunately, little effort has been made to test the extent to which differences in the environment might promote changes in the epifauna associated with a given substrate. As mentioned above, most of the species considered here are generalists, so this epifaunal community presumably responds to factors other than just variations in Eudendrium sp. properties and abundances. Tanner (2006) highlighted the importance of landscape ecology for the mobile epifauna associated with seagrasses. A factor frequently used to explain the diversity decrease of sessile animals in marine caves is the difficulty involved in reaching and colonizing this semi-enclosed environment (Harmelin 1997, Denitto et al. 2007). Nevertheless, this does not seem to be a 
plausible explanation for mobile epifaunal community, since movement of the major mobile groups associated with hard-bottom substrates is mainly accomplished by crawling from one substrate to another, rather than swimming in the water column (Taylor 1998b). Moreover, amphipods lack planktonic larvae, and there is no discontinuity between internal and external stations in the presence of Eudendrium sp. in the caves we studied.

Trophic requirement is another main factor affecting the distribution and composition of the amphipod community (Conradi \& López-González 2001 and references therein), and the decrease in trophic supply is the most common explanation for impoverishment of cave faunas (Zabala et al. 1989). With the exception of some carnivorous (Amphilochus neapolitanus, Liljeborgia sp., and stenothoids), and herbivorous species (Elasmopus vachoni, Amphitoe ramondi, Perionotus testudo and Lysianassa costae) the rest of amphipods inhabiting Eudendrium sp. were detritivorous (Scipione 1989, Guerra-García et al. 2014). This association is favored by mucus secretion in the colonies, which retains large amounts of sediment from the water column (Bavestrello et al. 1994). Experimental studies in vegetated habitats revealed that species richness and abundance of amphipods were highly and positively related to the detritus content (Vázquez-Luis et al. 2009). However, while in most cases (e.g. harbours) low hydrodynamism conditions are related to higher sedimentation rates, marine caves often represent an exception. Due to the highly stable conditions in the caverns, protected from the influence of currents and storms, the amount of suspended particles in the water is very low (Fichez 1991). Because of this low siltation, food supply could be a limiting factor for the detritus-feeding community supported by cave substrates. The near absence of photosynthetic activity inside the cavity contributes to this low diversity as well, as it confines the presence of herbivorous species to illuminated areas (Harmelin et al. 1985, Parker et al. 2001). All herbivorous species found in this study were only present in the external stations.

Lastly, the structure and dynamics of marine epifauna can also be affected by predation pressure by fishes (Nelson 1979, Vázquez-Luis et al. 2010). Mobile epifauna constitute the most important trophic resource for the majority of demersal fishes, and the most productive fishes in rocky reef ecosystems (Taylor 1998a, Edgar \& Aoki 1993). Epifauna associated with hard-bottom substrates (mainly crustaceans) appear to be the most abundant food item for several species of the genus Diplodus, one of the dominant groups in shallow rocky habitats of the Mediterranean (Sala \& Ballesteros 1997). There are differences in the fish assemblages associated with marine caves and rocky cliffs, with a decrease in species richness and abundance toward the innermost sections of the caves (Bussotti et al. 2002, Bussotti \& Guidetti 2009). Therefore, a decrease in predation pressure would be expected inside marine caves. Nevertheless, it is not clear which is the primary controlling factor in these systems; prey availability (bottomup regulation) or predation pressure (top-down regulation). In this sense, Taylor (1998a) found that these fishes only consumed approximately $20 \%$ of epifaunal production, although this work was carried out in New Zealand and his results are difficult to extrapolate to our environments. Edgar \& Aoki (1993) also suggested that fish predation affects size structure and composition (preferentially eliminating the largest animals), rather than epifaunal production.

In conclusion, we suggest that the oligotrophic conditions inside the caves, in conjunction with the absence of algae, were the main factors influencing the diversity and species composition in epifaunal communities of marine cave ecosystems. Further studies will be necessary to clarify the role of predation over epifaunal ecology, and vice versa. In that sense, marine caves represent an ideal environment in which to conduct ecological and experimental investigations because of their impoverished communities, isolated conditions and the strong gradients in predation pressure and epifaunal abundance present in these habitats.

Acknowledgements. Financial support of this work was provided by the Ministerio de Economía y Competitividad (Project CGL 2011-22474, internal reference 2011-707) cofinanced by FEDER funds of the European Union, and by the Consejería de Economía, Innovación, Ciencia y Empleo, Junta de Andalucía (Project P11-RNM-7041). Special thanks to Dr. E. Baeza-Rojano for help with amphipod identifications. Constructive comments on the manuscript from 3 anonymous reviewers were much appreciated. We are also grateful to K. Gavira and E. Hendrycks, who conducted the English revision of the manuscript, and to I. Ferreira for help in sorting the samples. This work forms part of C.N-B.'s PhD thesis, supported by the University of Seville (PIF Grant).

\section{LITERATURE CITED}

Bamber RN, Evans NJ, Robbins RS (2008) The marine softsediment benthic communities of Hong Kong: a comparison of submarine cave and open habitats. J Nat Hist 42: 953-965

Bavestrello G, Cerrano C, Cattaneo-Vietti R (1994) Colonies of Eudendrium glomeratum (Cnidaria, Hydromedusae) as sediment traps on vertical rocky cliffs. Boll Mus Ist Biol Univ Genova 58-59:125-130 
Bavestrello G, Cerrano C, Cattaneo-Vietti R, Sarà M (1996) Relations between Eudendrium glomeratum (Cnidaria, Hydromedusae) and its associated vagile fauna. Sci Mar 60:137-143

Bavestrello G, Puce S, Cerrano C, Zocchi E, Boero N (2006) The problem of seasonality of benthic hydroids in temperate waters. Chem Ecol (Suppl 1)22:S197-S205

Bellan-Santini D, Karaman G, Krapp-Schickel G, Ledoyer M, Myers AA, Ruffo S, Schiecke U (1982) Gammaridae (Acanthonotozomatidae to Gammaridae). In: Ruffo S (ed) The Amphipoda of the Mediterranean, Part I. Mémories de l'Istitut Océanographique, Monaco

Bellan-Santini D, Diviacco G, Krapp-Schickel G, Myers AA, Ruffo S (1989) Gammaridae (Haustoriidae to Lysianassidae). In: Ruffo S (ed) The Amphipoda of the Mediterranean, Part II. Mémories de l'Istitut Océanographique, Monaco

Bellan-Santini D, Karaman G, Krapp-Schickel G, Ledoyer M, Ruffo S (1993) Gammaridae (Melphidippidae to Talitridae), Ingolfiellidea and Caprellidea. In: Ruffo S (ed) The Amphipoda of the Mediterranean, Part III. Mémories de l'Istitut Océanographique, Monaco

> Benedetti-Cecchi L, Airoldi L, Abbiati M, Cinelli F (1997) Exploring the causes of variation in assemblage of benthic invertebrates from a submarine cave with sulphur springs. J Exp Mar Biol Ecol 208:153-168

> Birdsey EM, Johnston EL, Poore AGB (2012) Diversity and cover of a sessile animal assemblage does not predict its associated mobile fauna. Mar Biol 159:551-560

Bradshaw C, Collins P, Brand AR (2003) To what extent does upright sessile epifauna affect benthic biodiversity and community composition? Mar Biol 143:783-791

> Bussotti S, Guidetti P (2009) Do Mediterranean fish assemblages associated with marine caves and rocky cliffs differ? Estuar Coast Shelf Sci 81:65-73

> Bussotti S, Denitto F, Guidetti P, Belmonte G (2002) Fish assemblages in shallow marine caves of the Salento Peninsula (Southern Apulia, SE Italy). Mar Ecol 23: 11-20

Bussotti S, Terlizzi A, Fraschetti S, Belmonte G, Boero F (2006) Spatial and temporal variability of sessile benthos in shallow Mediterranean marine caves. Mar Ecol Prog Ser 325:109-119

Carvalho S, Cúrdia J, Pereira F, Guerra-García JM, Santos MN, Cunha MR (2014) Biodiversity patterns of epifaunal assemblages associated with the gorgonians Eunicella gazella and Leptogorgia lusitanica in response to host, space and time. J Sea Res 85:37-47

Chapman MG, People J, Blockley D (2005) Intertidal assemblages associated with natural coralline turf and invasive mussel beds. Biodivers Conserv 14:1761-1776

Chemello R, Milazzo M (2002) Effect of algal architecture on associated fauna: some evidence from phytal mollusks. Mar Biol 140:981-990

Clarke KR, Gorley RN (2001) PRIMER (Plymouth Routines in Multivariate Ecological Research) v5: user manual/ tutorial. PRIMER-E, Plymouth

Conradi M, López-González PJ (2001) Relationships between environmental variables and the abundance of peracarid fauna in Algeciras Bay (southern Iberian Peninsula). Cienc Mar 27:481-500

Conradi M, López-González PJ, Cervera JL, García-Gómez JC (2000) Seasonality and spatial distribution of peracarids associated with the bryozoan Bugula neritina in Algeciras Bay, Spain. J Crustac Biol 20:334-349
Dean HK (2008) The use of polychaetes (Annelida) as indicator species of marine pollution: a review. Rev Biol Trop 56:11-38

> Denitto F, Terlizzi A, Belmonte G (2007) Settlement and primary succession in a shallow submarine cave: spatial and temporal benthic assemblage distinctness. Mar Ecol 28:35-46

Di Camillo CG, Bo M, Lavorato A, Morigi C, Segre-Reinach M, Puce S, Bavestrello G (2008) Foraminifers epibionthic on Eudendrium (Cnidaria: Hydrozoa) from the Mediterranean Sea. J Mar Biol Assoc UK 88:485-489

> Di Camillo CG, Betti F, Bo M, Martinelli M, Puce S, Vasapollo C, Bavestrello G (2012) Population dynamics of Eudendrium racemosum (Cnidaria, Hydrozoa) from the North Adriatic Sea. Mar Biol 159:1593-1609

> Duffy JE, Hay ME (1991) Food and shelter as determinant of food choice by an herbivorous amphipod: the roles of selectivity, mixing, and compensation. Mar Ecol Prog Ser 218:249-266

> Duffy JE, Hay ME (2000) Strong impacts of grazing amphipods on the organization of a benthic community. Ecol Monogr 70:237-263

Edgar GJ, Aoki M (1993) Resource limitation and fish predation: their importance to mobile epifauna associated with Japanese Sargassum. Oecologia 95:122-133

Engqvist L (2005) The mistreatment of covariate interaction terms in linear model analyses of behavioural and evolutionary ecology studies. Anim Behav 70:967-971

Fichez R (1991) Suspended particulate organic matter in a Mediterranean submarine cave. Mar Biol 108:167-174

Fredriksen S, Christie H, Sæthre BA (2005) Species richness in macroalgae and macrofauna assemblages on Fucus serratus L. (Phaeophyceae) and Zostera marina L. (Angiospermae) in Skagerrak, Norway. Mar Biol Res 1:2-19

> Gerovasileiou V, Voultsiadou E (2012) Marine caves of the Mediterranean Sea: a sponge biodiversity reservoir within a biodiversity hotspot. PLoS ONE 7:e39873

> Gestoso I, Olabarria C, Troncoso JT (2013) Selection of habitat by a marine amphipod. Mar Ecol doi:10.1111/ maec. 12068

- Guerra-García JM, García-Gómez JC (2001) Spatial distribution of Caprellidea (Crustacea: Amphipoda): a stress bioindicator in Ceuta (North Africa, Gibraltar area). Mar Ecol 22:357-367

Guerra-García JM, Cabezas MP, Baeza-Rojano E, Izquierdo D and others (2011) Abundance patterns of macrofauna associated to marine macroalgae along the Iberian Peninsula. Zool Baetica 22:3-17

Guerra-García JM, Tierno de Figueroa JM, Navarro-Barranco C, Ros M, Sánchez-Moyano JE, Moreira J (2014) Dietary analysis of the marine Amphipoda (Crustacea: Peracarida) from the Iberian Peninsula. J Sea Res 85: 508-517

Harmelin JG (1997) Diversity of bryozoans in a Mediterranean sublittoral cave with bathyal-like conditions: role of dispersal processes and local factors. Mar Ecol Prog Ser 153:139-152

Harmelin JG, Vacelet J, Vasseur P (1985) Les grottes sousmarines obscures: un milieu extrême et un remarquable biotope refuge. Tethys 11:214-229

Hiscock K, Breckels M (2007) Marine biodiversity hotspots in the UK: a report identifying and protecting areas for marine biodiversity. WWF, Plymouth

Huitema BE (2011) The analysis of covariance and alternatives: statistical methods for experiments, quasi- 
experiments, and single-case studies, 2nd edn. John Wiley, Hoboken, NJ

Janssen A, Chevaldonné P, Martínez-Arbizu P (2013) Meiobenthic copepod fauna of a marine cave (NW Mediterranean) closely resembles that of deep-sea communities. Mar Ecol Prog Ser 479:99-113

Ledoyer M (1966) Écologie de la faune vagile des biotopes méditerranéens accessibles en scaphandre autonome. Introduction: données analytiques sur les biotopes de substrat dur. Rec Trav Sta Mar Endoume 40:103-149

Martí R, Uriz MJ, Ballesteros E, Turon X (2004) Benthic assemblages in two Mediterranean caves: species diversity and coverage as a function of abiotic parameters and geographic distance. J Mar Biol Assoc UK 84:557-572

Martin-Smith KM (1993) Abundance of mobile epifauna: the role of habitat complexity and predation by fishes. J Exp Mar Biol Ecol 174:243-260

> Martins GM, Hawkins SJ, Thompson RC, Jenkins SR (2007) Community structure and functioning in intertidal rock pools: effects of pool size and shore height at different successional stages. Mar Ecol Prog Ser 329:43-55

- Navarro-Barranco C, Guerra-García JM, Sánchez-Tocino L, García-Gómez JC (2012) Soft-bottom crustacean assemblages in Mediterranean marine caves: the cave of Cerro Gordo (Granada, Spain) as case study. Helgol Mar Res 66:567-576

> Navarro-Barranco C, Guerra-García JM, Sánchez-Tocino L, Jiménez-Prada P, Cea S, García-Gómez JC (2013) Softbottom diversity patterns in marine caves; lessons from crustacean community. J Exp Mar Biol Ecol 446:22-28

Nelson WG (1979) Experimental studies of selective predation on amphipods: consequences for amphipod distribution and abundance. J Exp Mar Biol Ecol 38:225-245

Parker JD, Duffy JE, Orth RJ (2001) Plant species diversity and composition: experimental effects on marine epifaunal assemblages. Mar Ecol Prog Ser 224:55-67

Poore AGB, Watson MJ, de Nys R, Lowry JK, Steiberg PD (2000) Patterns of host use among alga- and spongeassociated amphipods. Mar Ecol Prog Ser 208:183-196

Quinn GP, Keough MJ (2002) Experimental design and data analysis for biologists. Cambridge University Press, Cambridge

Romagnoli T, Bavestrello G, Cucchiari EM, De Stefano M and others (2007) Microalgal communities epibiontic on the marine hydroid Eudendrium recemosum in the Ligurian Sea during an annual cycle. Mar Biol 151: $537-552$

Sala E, Ballesteros E (1997) Partitioning of space and food resources by three fish of the genus Diplodus (Sparidae) in a Mediterranean rocky infralittoral ecosystem. Mar Ecol Prog Ser 152:273-283

Sánchez-Moyano JE, García-Gómez JC (1998) The arthropod community, especially Crustacea, as a bioindicator in Algeciras Bay (Southern Spain) based on a spatial distribution. J Coast Res 14:1119-1133

Scipione MB (1989) Comportamento trofico dei Crostacei

Editorial responsibility: Christine Paetzold,

Oldendorf/Luhe, Germany
Anfipodi in alcuni sitemi bentonici costieri. Oebalia 15: 249-260

Scipione MB, Taramelli E, Fresi E, Cinelli F, Mazzella L (1981) Distribuzione delle biocenosi bentoniche lungo un gradiente di luce in una grotta marina superficiale: Anfipodi. Mem Biol Mar Oceanogr 11:1-16

Shannon CE, Weaver N (1963) The mathematical theory of communication. University of Illinois Press, Urbana

Simkina RG (1980) A quantitative feeding study of the colonies of Perigonimus megas (Hydroida, Bougainvillidae). Zool Zh 59:500-506

> Stella JS, Jones GP, Pratchett MS (2010) Variation in the structure of epifaunal invertebrate assemblages among coral hosts. Coral Reefs 29:957-973

Tanner JE (2006) Landscape ecology of interactions between seagrass and mobile epifauna: the matrix matters. Estuar Coast Shelf Sci 68:404-412

Taylor B (1997) The role of small mobile epifauna in subtidal rocky reef ecosystems. PhD thesis, University of Auckland

Taylor B (1998a) Density, biomass and productivity of animals in four subtidal rocky reef habitats: the importance of small mobile invertebrates. Mar Ecol Prog Ser 172: $37-51$

Taylor B (1998b) Short-term dynamics off a seaweed epifaunal assemblage. J Exp Mar Biol Ecol 227:67-82

True MA (1970) Étude quantitative de quatre peuplements sciaphiles sur substrat rocheux dans la région marseillaise. Bull Inst Ocean Monaco 1410:1-48

Underwood AJ (1997) Experiments in ecology: their logical design and interpretation using analysis of variance. Cambridge University Press, Cambridge

Underwood AJ, Chapman MG, Richards SA (2002) GMAV-5 for Windows: an analysis of variance programme. University of Sydney

- Vacelet J, Boury-Esnault N, Harmelin JG (1994) Hexactinelid cave, a unique deep-sea habitat in the scuba zone. Deep-Sea Res 41:965-973

Vader W, Krapp-Schickel G (1996) Redescription and biology of Stenothoe brevicornis Sars (Amphipoda: Crustacea), an obligate associate of the sea anemone Actinostola callosa (Verrill). J Nat Hist 30:51-66

Vázquez-Luis M, Borg JA, Sánchez-Jerez P, Png L, Carvallo M, Bayle-Sempere JT (2009) Why amphipods prefer the new available habitat built by $C$. recemosa: a field experiment in Mediterranean Sea. Proc 2nd Int Symp Mar Sci, University of Alicante

Vázquez-Luis M, Sánchez-Jerez P, Bayle-Sempere JT (2010) Effects of Caulerpa racemosa var. cylindracea on prey availability: an experimental approach to predation of amphipods by Thalassoma pavo (Labridae). Hydrobiologia 654:147-154

Zabala M, Riera T, Gili JM, Barange M, Lobo A, Peñuelas J (1989) Water flow, trophic depletion, and benthic macrofauna impoverishment in a submarine cave from the western Mediterranean. Mar Ecol 10:271-287

Submitted: January 11, 2013; Accepted: November 27, 2013

Proofs received from author(s): January 16, 2014 